\title{
Brief Analysis on a Poem Incident by Countee Cullen
}

\author{
GUAN Xing-hua* \\ Guangdong University of Finance, Guangzhou, China.
}

*Corresponding Author: GUAN Xing-hua, Guangdong University of Finance, Guangzhou, China.

\begin{abstract}
There are many works reflecting the racial discrimination in the United States. But while reading the short poem Incident written by Countee Cullen, we are still shocked, because it is viewed from a different perspective, that is from the child's point of view. This poem was published in 1925. Time flies. Nearly a century has passed. The racial discrimination in American society has not been reduced with the time going by. But it has become more and more intense, especially since the COVID-19 in 2020 and 2021. While rereading the poems published one hundred years ago, we have a further and even a deeper understanding of this social problem of America.
\end{abstract}

Key Words: poem; racism; discrimination; African American; prejudice

While looking up at a beautiful summer night sky, one praises not only the beauty of the silvery moon but also that of those twinkling little stars. For the same reason, we appreciate in the field of writers such big and greatest ones as Edgar Allan Poe, Hemingway, and Mark Twain, and celebrate at the same time other lesser ones, of them Countee Cullen is one. We must remember, however, that though not as big and great, Countee Cullen is just as unique and important.

Countee Cullen, whose real surname was Porter, was born on May 30, 1903. Nothing is known about where he was born, and little is known of his parents. An orphan in New York City, he was adopted by Mrs. Carolyn Cullen, whose name he took. Following graduation from DeWitt Clinton High School, where he won a high school poetry contest, he attended New York University. In 1925 he took a baccalaureate degree, and his first book of poems, 《Color》, was published. He earned a master's degree at Harvard and then became assistant editor of Opportunity: Journal of Black Life.

Cullen knew what was going on in African American life, but he was not deeply involved. 《Ballad of the Brown Girl》 and 《Copper Sun》, both published in 1927. By 1929 Cullen had published four volumes of poetry. The title poem of 《The Black Christ and Other Poems》. His novel, 《One Way to Heaven》, satirizes upper-class African American life. 《The Lost Zoo And My Nine Lives and How I Lost Them》are children's books. Cullen died on Jan. 9, 1946. The following poem Incident is taken from his collection of poem 《Color》.

In his Incident, the poet uses the first-person point of view and tells us what "I" experienced. But in the end what happened for him. Now let us read the poem.

\section{Incident 一件小事}

\section{By Countee Cullen}

Once riding in old Baltimore

Heart-filled, head-filled with glee,

I saw a Baltimorean

Keep looking straight at me.

Now I was eight and very small,

And he was not whit bigger,

And so I smiled, but he poked out

His tongue, and called me, "Nigger".

I saw the whole of Baltimore

From May until December,

Of all the things that happened there,

That is all that I remember.

\section{那天我骑马走在巴尔的摩市, 兴高采烈, 又满心欢喜。 我看到一个巴尔的摩人 直盯着我, 眼睛怪异。}

那时我还小, 刚刚满八岁, 他比我也大不了一半岁。 所以我冲他笑笑, 可他, 吐吐舌头, 叫我“黑鬼”。

我看了整个巴尔的摩市, 从五月一直到年底,

那儿发生了所有事当中, 这是我唯一记得的一件事。
那天骑马走巴市, 兴高采烈心欢喜。 目视巴人走过来, 眼睛盯我很怪异。

我们两个一般大, 八岁小孩无恶意。 于是抬头示笑脸, 向他微微表善意。

可他吐舌叫黑鬼。 我看巴市半年里, 其它事情全忘记, 唯有此事记心底。 
In the first two lines of the poem, we can read the poet at the time was incredibly happy and cheerful. He is "Heart-filled, head-filled with glee". He rode a pony to have a sightseeing of Baltimore, a city both of old and modern, which is 60 miles away from Washington D.C... Baltimore is a beautiful seaside city. While walking on the quiet street, the poet was in high spirit. Here the author uses jump sentence to describe his happiness while riding on the horse. From the two lines of poem, we can see that in the eyes of the author at the time everything is good. And he was satisfied with all this. It seems as if the sky was blue and the trees were green. The sun was shining, and the breeze is pleasant.

After reading the following two lines of the poem, we can sense something would happen. He saw a Baltimorean "looking straight at me". From the word "straight", we feel a strange thing probably would take place. As matter of fact, at this the author did not tell us what would happen and what kind of person the Baltimorean was.

Now let us come to the first two lines of the second stanza. We read "Now I was eight and very small. And he was not whit bigger". The fact was that "I" and "He" were little children, eightor nine years old children. The two boys were strangers to each other. There would be nothing

important that would happen for them. Now that they were in the same age, so "I" smiled to "He" to show friendship to him. But what response he gave made the black boy surprised and annoyed. He poked out his tongue, and called him, "Nigger".

In America society, it is not allowed to call the black people a nigger or a negro, especially to their face. If you do, he or she will kill you if he has a gun at hand. Because it is such an insulting and pejorative language used, so as no one in black society can endure. You can say "You are a black". It is acceptable.

In the first stanza of the poem, we know the poet was extremely glad, happy, and cheerful. But when he heard the little boy called him "Nigger", he was frustrated so much that he felt he was insulted. He was provoked. He was belittled. The poet' heart began to become heavier and heavier. No word could be chosen to express that feeling of his at the time. He suffered a lot. Originally his happy mood disappears completely. To him it seems as if the sky was not blue, but dark and the trees were not green, but gray. The sun was not shining, but raining and the breeze was not pleasant, but cold, very cold.

Two children of the same age treat each other so differently. What had happened to them? The poet did not explain to us at the end of the Incident. But it is very clearly that he described he had lived in Baltimore for more than six months, so many things had happened there, but he had forgotten all but only this nothing more.

We have read many works about the racial discrimination in America, but this poem is still very shocking to us. Because it has been viewed from a different perspective, that is from a little child's point of view. Each of us has a childhood of eight or nine years old. Not so much of what had happened then has still survived in our memory until today. Opening the dusty years of the past, only those memories that is often too sweet or too bitter cannot be easily erased. It is self-evident that this kind of bitterness let the child never forget, which gives a great negative influence on his whole life. We could imagine that after this "incident" the black child lost his innocence and self-esteem. And in the end, he became silent and depressed.

Perhaps, this was the first time for the black child to be conscious of a great difference between man and man. And that was also the first time for him to recognize his own inferiority being a black. With such treatment and cognition, he would not be so happy and carefree as he had been. And from then on, he would not like the world at all and love the people around him either. As for the white child, he was only nine years old. But in his childhood heart the seeds of racial discrimination had been planted, the prejudice of which would affect his whole life. And then, in his future, this influence of such a prejudice would be enlarged and became stronger step by step. It was unfair not only for the black boy but also for the white one. The thought of the effect of such an "Incident" on two innocent children makes us realize that there was, and there is, and there will be racism in America. Time has been proved it and will prove it. This injustice for the black people is unfair.

Countee Cullen published this poem a long time ago, which appeared in public in 1925 . Nearly a hundred years ago, there were a racism or racial discrimination in America society. The people in whole ranks were struggle and fighting against this social injustice. But look at nowadays society in 
America, the same thing has been taking place all over America and over and over again, day in and day out. The black people are still going on to the street to have demonstration against the racial injustice. Especially in 2020 and 2021, owing to the Covid-19 virous affect, the black people suffer even worse. So many black people and African Americans died of this disease compared with the white people in US. And at the same time many African American are more severely discriminated than ever before. Many people died not only of the disease, but of the police gunpowder. This is the systematic social problem. We do not think the America government can solve this problem. There is really no hope we can have. It is no use for the black people to go to the street to demonstrate upholding the slogan "Black lives matter". For the white and elite people, the black people's lives do not matter to them at all. That is the seeds planted from 100 years or even longer ago. From the poem we can come into this conclusion.

Countee Cullen was one of the most widely recognized as African American poets, though he was less concerned with social and political problems than were his African American contemporaries. He is noted for his lyricism and artful use of imagery. He is a black.

The words used in this poem are very plain and concise. A language Countee Cullen used is very much like the simplicity by Hemingway. It seems as if there is a man quietly narrating and telling a story, just like a storyteller. The language is quite simple but without losing its greatness. The profound impact upon the society is great, from which we can say Countee Cullen was a great poet in the American literature. And he is a little star twinkling in the sky not only in America but the world over.

The Incident is a metrical poem. It is divided into three stanzas, 12 lines. It is iambic tetrameter. The rhyme is the end rhyme. It is simple and it is easy to read. And it is easy to recite as well. While reading aloud this poem, Incident, we must try to imagine the situation, listening to the sounds, visualizing the scene and feeling the rhythm. Ah, a good poem.

\section{REFERENCES}

[1] Ernest Hemingway, Old Man and Sea, Publisher, Simon \& Schuster US 1995.

[2] Countee Cullen, Biography 1903-1946.

[3] Countee Cullen, Ballad of the Brown Girl 1927.

[4] Countee Cullen, Copper Sun 1927.

[5] Countee Cullen, the Black Christ and Other Poems 1929.

[6] Countee Cullen, Color 1925.

[7] Steele, C. Whistling Vivaldi: And Other Clues to How Stereotypes Affect Us and What We Can Do. 2011.

[8] Brown, A. C. I am Still Here: Black Dignity in a World Made for Whiteness 2018.

[9] Kendi, I. X. How to Be an Antiracist, One World 2019.

[10] McCann, C. Apeirogon. Random House 2020.

[11] 刘祚昌, 美国内战期间黑人反对种族歧视的斗争《史学月刊》1964年第09期

\section{AUTHOR'S BIOGRAPHY}

Guan Xinghua, Professor of English at Guangdong University of Finance. The main research direction is English and American literature and English teaching. Email: gxh0330@126.com

Citation: Guan Xinghua. "Brief Analysis on a Poem Incident by Countee Cullen" International Journal of Humanities Social Sciences and Education (IJHSSE), vol 8, no. 6, 2021, pp. 7-9. doi: https://doi.org/10.20431/2349-0381.0806002.

Copyright: (1) 2021 Authors. This is an open-access article distributed under the terms of the Creative Commons Attribution License, which permits unrestricted use, distribution, and reproduction in any medium, provided the original author and source are credited. 